\title{
Some problems pertaining to superlarge ore deposits of China
}

\begin{abstract}
'Superlarge' mineral deposits are those in which the proved ore reserves are more than five times the reserves of 'large' deposits, as defined by the China Ore Reserves Committee. Superlarge deposits correspond well with the 'giant' deposits of some other scientists for certain metals but differ for others. For exploration purposes, it is important to know that the mineralisation types of superlarge ore deposits are generally very limited in number. It is noticeable that many of China's superlarge deposits lies on the borders of the North China craton, as well as the Yangtze craton. As for the temporal distribution, Proterozoic, Palaeozoic and Mesozoic ages are more common, while Archaean and Tertiary superlarge deposits are much less significant. The presence of abundant volatiles, alkali metals, synchronous structures and the clustering of various mineralisation types in one deposit are considered as necessary factors in the formation of some superlarge mineral deposits.
\end{abstract}

\section{Definition}

There seems to be no consensus of opinion on the definition of superlarge ore deposits and similar terms, such as giant, world class and, especially large ore deposits (Duke, 1994).

Superlarge ore deposits here refer to those deposits in which the proved ore reserves are more than five times the reserves of large deposits. The demarcations among large-medium- and small-scale ore deposits were established by the China Ore Reserves Committee in 1987 for each metallic and non-metallic deposit. For many nonferrous and precious metallic deposits, such as those of $\mathrm{Cu}, \mathrm{Pb}-\mathrm{Zn}$, $\mathrm{Hg}, \mathrm{Sn}, \mathrm{Ag}$ and $\mathrm{Au}$, our superlarge deposits correspond well with the giant deposits of Laznicka (1983). As defined by the latter, the giant ore deposits have a tonnage accumulation index (economic metal tonnage in the ore deposit/crustal mean metal content in ppm) in excess of $10^{11}$. However, for some other metallic deposits, such as those of $\mathrm{Sb}, \mathrm{Ni}$ and $\mathrm{Bi}$, the differences may be very large (Table 1).

We adopt the scales set by the China Ore Reserves Committee since they fit well with the mineral resources situations in China and because they can be applied to both metallic and non-metallic deposits (Laznicka's definition for giant deposits can only be used for metallic deposits).

\section{Main types of superlarge metallic deposits of China}

For each metal, there are usually several types of mineralization with industrial significance. For example, China is a country rich in Mo, of which ore accumulations are found in skarns, quartz veins, por-
Table I Comparison of Laznicka's giant deposits with our superlarge metal ore deposits.

$\begin{array}{ccc}\begin{array}{c}\text { Mean crustal content } \\ (\mathrm{ppm})\end{array} & \begin{array}{c}\text { Giant deposits } \\ \text { (Mt) }\end{array} & \begin{array}{c}\text { Superlarge deposits } \\ \text { (Mt) }\end{array} \\ \text { (Vinogradov, 1962) } & \text { (Laznicka, 1983) } & \text { (Tu, this paper) }\end{array}$

\begin{tabular}{llll}
\hline $\mathrm{Cu}$ & 47 & $>4.7$ & $>2.5$ \\
$\mathrm{~Pb}$ & 16 & $>1.6$ & $>2.5$ \\
$\mathrm{Zn}$ & 83 & $>8.3$ & $>2.5$ \\
$\mathrm{Ni}$ & 58 & $>5.8$ & $>0.5$ \\
$\mathrm{Mo}$ & 1.1 & $>1.1$ & $>0.5$ \\
$\mathrm{Sb}$ & 0.5 & $>0.05$ & $>0.5$ \\
$\mathrm{~W}$ & 1.3 & $>0.13$ & $>0.25$ \\
$\mathrm{Bi}$ & 0.009 & $>0.009$ & $>0.25$ \\
$\mathrm{Sn}$ & 2.5 & $>0.25$ & $>0.2$ \\
$\mathrm{Hg}$ & 0.083 & $>0.0083$ & $>0.01$ \\
$\mathrm{Au}$ & 0.0034 & $>0.00034$ & $>0.001$ \\
$\mathrm{Ag}$ & 0.07 & $>0.007$ & $>0.005$
\end{tabular}

phyries, subaerial volcanic rocks (with $\mathrm{U}$ ) and red beds (with $\mathrm{Cu}$ ). But there are only two known superlarge Mo deposits both of which are of porphyry type (Table 2).

The same tendency applies to other metals. Since China is also rich in Sn, we can cite Sn deposits as another example. There are at present two superlarge $\mathrm{Sn}$ deposits known in China and it is interesting to note that these are of only one type - the cassiterite-sulphide type, with stratabound massive sulphides of $\mathrm{Fe}, \mathrm{Pb}, \mathrm{Zn}$ and $\mathrm{Sb}$ superimposed by $S n$-bearing granite. Other mineralization types, such as greisen, skarn, porphyry etc.. are also of industrial importance, but have no superlarge representatives.

For the base metals such as $\mathrm{Cu}, \mathrm{Pb}$ and $\mathrm{Zn}$, mineralization types of their respective superlarge ore deposits are somewhat more complex. However, generally not more than three types of mineralization are encountered for the superlarge deposits of these metals. For example, industrial Cu ores can be found in the following mineralization types in China: skarns, porphyries, submarine volcano-sedimentary formations, subaerial volcanic rocks, $\mathrm{Fe}-\mathrm{Cu}$ associations, stratabound types in dolomites and sandstones and $\mathrm{Ni}-\mathrm{Cu}$ sulphide types related to basic-ultrabasic rocks. However, so far superlarge $\mathrm{Cu}$ deposits in China are essentially of porphyry type of Late Palaeozoic, Mesozoic and Cenozoic ages. the $\mathrm{Ni}-\mathrm{Cu}$ sulphide types and the stratabound type in dolomites are second and third in size. Although skarn $\mathrm{Cu}$ deposits of China are important economically and often produce rich ores, they are scarcely the size of superlarge deposits. This also applies to $\mathrm{Cu}$ deposits in volcanic formations.

$\mathrm{Pb}-\mathrm{Zn}$ ore deposits are widely distributed in China. They occur in skarns, submarine and subaerial volcanic formations, porphyries, sandstones and conglomerates, carbonate rocks in MVT (Mississippi Valley-type) and fine-grained clastic rocks in SEDEX (sedimentary exhalative) type. The economically important MVT deposits are well known in China and are concentrated in certain areas. Thus in the border region of Guizhou, Yunnan and Sichuan provinces, in an area of about $30000 \mathrm{~km}^{2}$, 60 MVT deposits occur. However, deposits of this type rarely reach superlarge size. The Fankou deposit is the only example of a superlarge MVT Pb-Zn deposit in China. By way of contrast, there are a few SEDEX Pb-Zn deposits in China, but 
Table 2 Main types of non-ferrous and precious metals superlarge deposits of China.

\begin{tabular}{lll} 
Metal & Type & Locality \\
\hline $\mathrm{Cu}$ & $\begin{array}{l}\text { Cu porphyry } \\
\text { Stratabound }\end{array}$ & $\begin{array}{l}\text { Dexin, Yulong, Dobaoshan } \\
\text { Dongchuan }\end{array}$ \\
$\mathrm{Pb}, \mathrm{Zn}$ & $\begin{array}{l}\text { Sedimentary exhalative (SEDEX) } \\
\text { Missisippi Valley type (MVT) } \\
\text { Stratabound in marine volcano- } \\
\text { sedimentary rocks and in } \\
\text { continental sediment }\end{array}$ & $\begin{array}{l}\text { Changba, Dongshenmiao } \\
\text { Fankou }\end{array}$ \\
& Jingding, Siteshan \\
$\mathrm{Ni}, \mathrm{Cu}$ & Cu-Ni sulphides & \\
$\mathrm{Mo}$ & Mo porphyry & Jinchuan \\
$\mathrm{Sn}$ & Cassiterite sulphides & Jinduecheng, Luanchuan \\
$\mathrm{W}-\mathrm{Bi}$ & Skarn+greisen & Gejiu, Dachang \\
$\mathrm{Sb}$ & Stratabound & Shizhuyuan \\
$\mathrm{Hg}$ & Stratabound & Sikuangshan \\
$\mathrm{Ag}$ & Ag-Pb, Zn porphyry & Wuchuan \\
$\mathrm{Au}$ & Stratabound & Lunsuikun \\
& Greenstone-granite & Bailiuchang \\
& Subaerial volcanics & Linlong, Jiaojia \\
& Meta-sedimentary formation & Jingguashi \\
& & Baguamiao
\end{tabular}

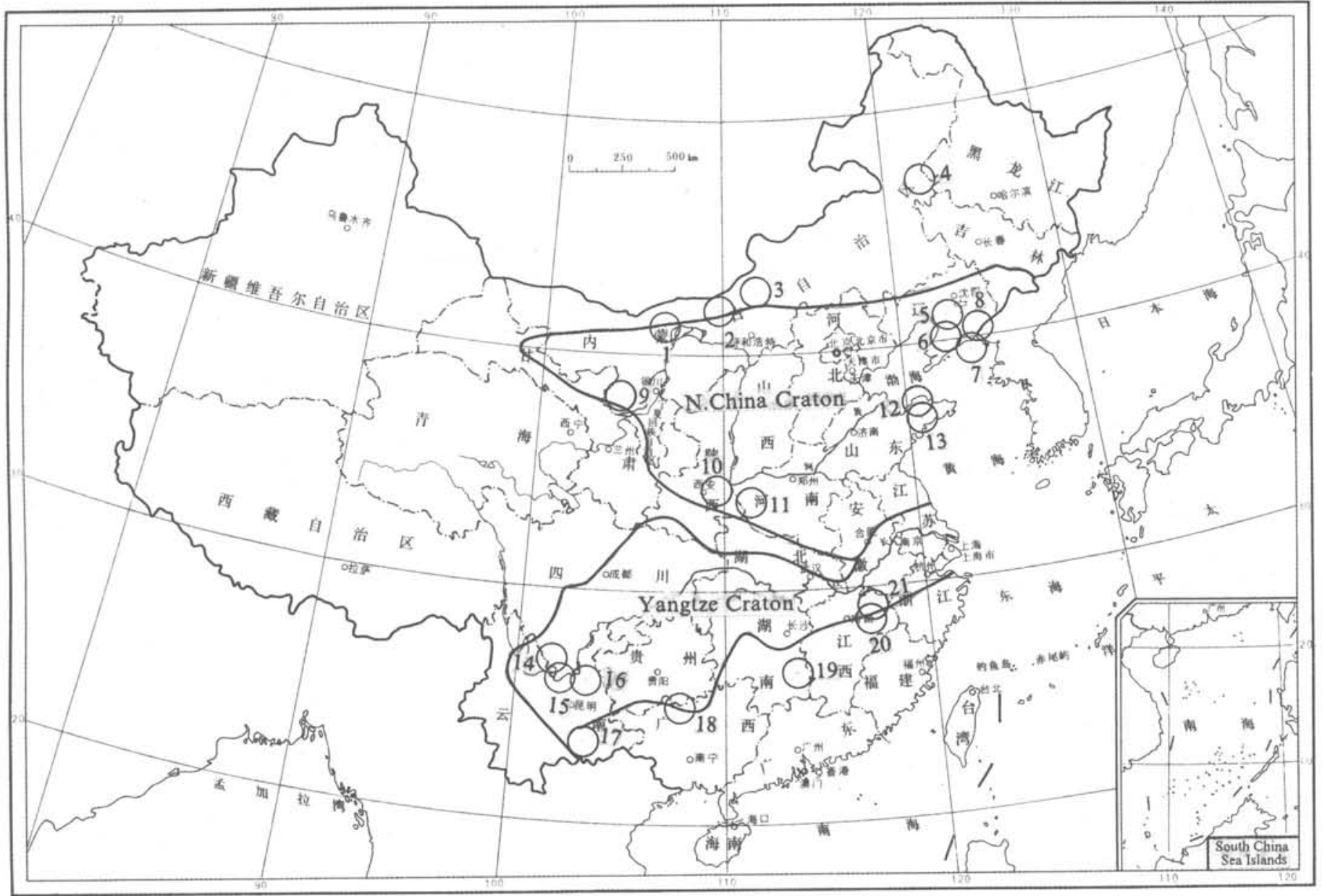

Figure 1 Simplified map showing superlarge deposits mainly located along the borders of cratons.

$\begin{array}{llllll}1 \mathrm{~Pb}-\mathrm{Zn} & 4 \mathrm{Zr} \text {-REE } & 7 \mathrm{Talc} & 10 \mathrm{Mo} & 13 \mathrm{Au} & 16 \mathrm{Cu} \\ 2 \mathrm{REE}-\mathrm{Fe}-\mathrm{Nb} & 5 \mathrm{Fe} & 8 \mathrm{~B}-\mathrm{Fe} & 11 \mathrm{Mo} & 14 \mathrm{~V} \text {-Ti-Fe } & 17 \mathrm{Sn} \text {-polymetal } 20 \mathrm{Cu} \\ 3 \text { Fluorite } & 6 \mathrm{Magnesite} & 9 \mathrm{Ni}-\mathrm{Cu} & 12 \mathrm{Au} & 15 \mathrm{~V} \text {-Ti-Fe } & 18 \mathrm{Sn} \text {-polymetal } 21 \mathrm{Cu}\end{array}$


they tend to form deposits of superlarge size. Two are currently known (Table 2). The tendency of SEDEX Pb- $\mathrm{Zn}$ mineralization to form superlarge deposits seems to be a worldwide phenomenon, as noted by Sangster (1994).

The Jinding superlarge stratabound $\mathrm{Pb}-\mathrm{Zn}$ deposit is unique and deserves attention. It occurs mostly in Tertiary freshwater clastic sediments at the boundary between the Indian and the Eurasian Plates. The isotopic composition of $\mathrm{Pb}$ in galena denotes that part of the $\mathrm{Pb}$ has a mantle origin.

Turning to precious metals, superlarge $\mathrm{Ag}-\mathrm{Pb}-\mathrm{Zn}$ deposits with $\mathrm{Ag}$ as the leading metal are essentially of two types in China: porphyry and stratabound. Superlarge Au deposits fall into three types: greenstone-granite, subaerial volcanic and meta-sedimentary. With data from deeper drilling becoming available, some Carlin-type Au deposits may attain superlarge size.

Taking the non-ferrous and precious metals as a whole, the stratabound type (for $\mathrm{Pb}-\mathrm{Zn}, \mathrm{Hg}, \mathrm{Sb}, \mathrm{Au}, \mathrm{Ag}, \mathrm{Cu}$ ) and porphyry type (for $\mathrm{Mo}, \mathrm{Cu}, \mathrm{Ag}, \mathrm{Au}$ ) are the most commonly observed mineralization types of superlarge deposits of China. $\mathrm{Ni}, \mathrm{W}$ and $\mathrm{Bi}$ are the main exceptions (Table 2).

\section{Spatial and temporal distribution of superlarge ore deposits of China}

There is a remarkable tendency for the superlarge ore deposits of China to lie along the borders of cratons (North China craton and Yangtze craton), either on the craton edges or in the neighbouring folded belts (Figure 1). These superlarge deposits are of various genetic and mineralization types and of different geologic ages. Some are confined to the rifts or the deep depressions (Bayun Obo $\mathrm{REE}-\mathrm{Fe}-\mathrm{Nb}$ deposit, Dongshenmiao $\mathrm{Pb}-\mathrm{Zn}$ deposit, etc.) along cratonic borders. This unique geographic distribution pattern of superlarge ore deposits owes its origin to multiple movements along plate margins during Proterozoic and Phanerozoic orogenies (Tu, 1994).

In costrast to many circumpacific countries where the Cenozoic is an important mineralization epoch for superlarge ore deposits, in east China many superlarge deposits formed in the Mesozoic during the well-known Yanshanian activation. As a whole, China's superlarge ore deposits are mostly of the Proterozoic and Phanerozoic. Cenozoic superlarge deposits are known only in the eastern extension of the Himalayan orogen and in Taiwan. Archean superlarge massive sulphide and gold deposits, which occur in Canada and Australia, are almost lacking in China, due to later reworking processes.

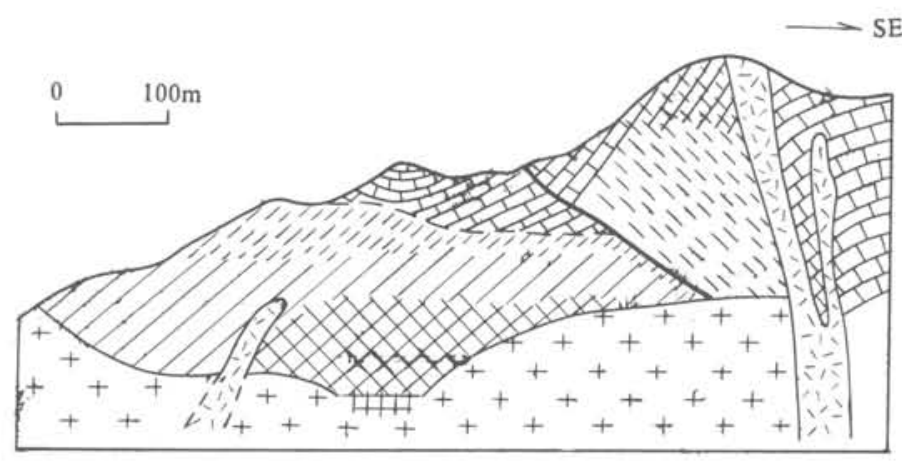

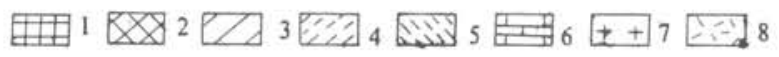

Figure 2 Section through the Shizhuyuan deposit, showing the locations of the four types of ore (after Chen et al., 1992).

1 greisen with $\mathrm{W}-\mathrm{Sn}-\mathrm{Mo}-\mathrm{Bi}$

2 skarn with W-Mo-Bi

3 skarn with $W-B i$

4 skarn with Bi

5 marble with cassiterite-

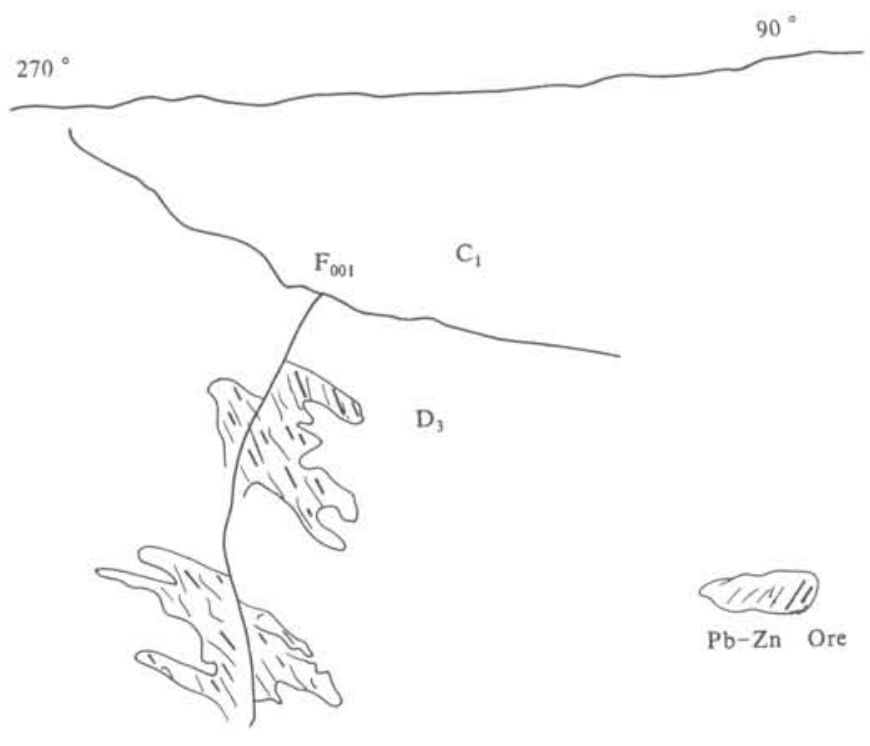

Figure 3 Simplified cross-section of the Fankou superlarge $\mathrm{Pb}-\mathrm{Zn}$ deposit, showing growth faulting which controls the ore distribution. This fault (F001) cut through the ore host D3 beds but stopped at the base of $\mathrm{Cl}$ in which there is no ore.

\section{The mechanism of formation of some superlarge ore deposits of China}

In quite a number of superlarge ore deposits of China, the accumulation of volatiles and alkali metals in the ores reaches an astonishing level. For example, in the Bayun Obo REE-Fe-Nb deposit, the amount of fluorite in various kinds of ore totals more than 130 million tonnes. Thus the Bayun Obo deposit probably ranks first in the world not only in its REE reserves, but also in the amount of fluorite. Phosphorus, contained in apatite, monozite and other minerals, is another important volatile in the ores of Bayun Obo. It is estimated that the amount of $\mathrm{P}$ may be in the region of 10 million tons (Qio, recent communication).

The Na silicate minerals, such as albite, acmite, aegirine and riebeckite, are probably even more widespread than fluorite and Pbearing minerals combined in the ores of the Bayun Obo deposit. A large quantity of $\mathrm{K}$ is also noticeable in the rocks overlying the ore.

The existence of huge amounts of alkali metals together with the volatile elements $\mathrm{F}$ and $\mathrm{P}$ (not counting $\mathrm{Cl}$, the amount of which is difficult to estimate) would certainly promote, to a great extent, the tranport of large quantities of such ore elements as REE, Nb, and Th in the form of easily soluble complexes. Thus, the presence of large reserves of alkali metals and volatiles is certainly an essential factor in the formation of the Bayun Obo superlarge ore deposit.

The Shizhuyuan superlarge W-Sn-Bi-Mo deposit is another example showing the significant role of volatiles in forming this huge deposit which has probably the largest reserves of both W and $\mathrm{Bi}$ in the world. According to Zhao (1995, oral communication), F ranges between 8.53 and $10.95 \%$ in different kinds of ores at Shizhuyuan, with total fluorite reserves around 50 million tonnes. Recent investigation by Liu (oral communication) gives the following values of $\mathrm{Cl} / \mathrm{F}$ in fluid inclusions: $1.12,0.66,0.80,0.74,0.95$ and 3.67 for early skarn, late skarn, massive greisen, vein greisen, quartz vein and carbonate vein respectively. This means that $\mathrm{Cl}$ and $\mathrm{F}$ were probably in equal amounts in the ore-forming solutions at Shizhiyuan. It is clear that the unusual amount of $\mathrm{Cl}$ and $\mathrm{F}$ served as a powerful transporting agency for $\mathrm{W}, \mathrm{Bi}, \mathrm{Sn}$ and $\mathrm{Mo}$ in the formation of the Shizhuyuan superlarge ore deposit.

There are different types of mineralization at Shizhuyuan. Figure 2 gives the geological cross-section of it, displaying the presence of greisen, different skarns and stockworks in marble, all with eco- 
nomic significance. This makes Shizhuyuan quite unique among several tens of $\mathrm{W}$ and $\mathrm{Bi}$ deposits in south China. Most of these deposits are of only one mineralization type, either quartz vein (Xihuashan and Pangushan), or skarn (Yaogangshan). The greisen type is of minor importance. So far, no superlarge ore deposits have been found among these single-type deposits. Thus, the clustering of various mineralization types in one deposit may be an important factor in making Shizhuyuan a superlarge ore deposit.

In some superlarge ore deposits of China, synchronous structures are well developed. Such structures find their expression in faults (Fankou $\mathrm{Pb}-\mathrm{Zn}$ deposit, Figure 3), rapid changes in facies and thickness of ore host beds (Bailiuchang $\mathrm{Ag}-\mathrm{Pb}-\mathrm{Zn}$ deposit and Bayun Obo deposit). Mineralizing solutions can migrate easily to the place of deposition with the help of synchronous structure, thus promoting the formation of superlarge ore deposits.

\section{References}

Chen, J, Halls, C, and Stanley, C J, 1992, Rare earth elements and patterns in major skarn minerals from Shizhuyuan W, Sn, Bi and Mo deposit, South China: Geochemical Journal, v. 26, pp.147-158

Duke, J M, 1994, Towards a definition of world class mineral deposits: Minerals Colloquium, Geological Survey of Canada, p.1
Laznicka, P, 1983, Giant ore deposits; a quantitative approach: Global Tectonics and Metallogeny, v. 2, pp.41-63

Sangster, D F, 1994, World class MVT and SEDEX lead-zinc deposits: Minerals Colloquium, Geological Survey of Canada, p.1

Tu Guangzhi, 1994, On the spatial distribution and mechanism of formation of superlarge mineral deposits of China: Abstracts, 9th Symposium of the International Association on the Genesis of Ore Deposits, p. 3

Guangzhi Tu is a Research Professor of ore deposit geochemistry at the Institute of Geochemistry, Chinese Academy of Sciences. Since receiving his doctorate from the University of Minnesota in 1949, he has been undertaking research on granitoid and related mineralisation, uranium, iron and gold deposits and stratabound deposits. His main publications are the monographs 'Geochemistry of granitoid in South China' and 'Geochemistry of stratabound ore deposits' (in 3 volumes). He is now conducting basic research on problems related to superlarge ore deposits in China.

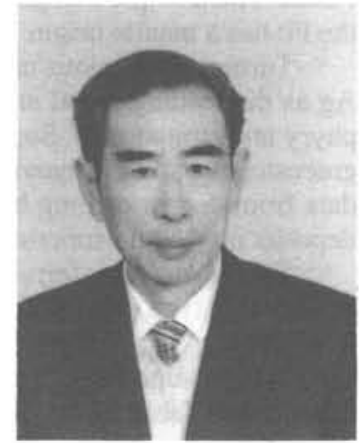

